\author{
Adam Dziurok \\ ORCID: https://orcid.org/0000-0001-6631-0544 \\ Historical Research Office of the Institute of National Remembrance, Katowice, Poland \\ Cardinal Stefan Wyszyński University in Warsaw, Poland
}

\title{
Actions against the Catholic Church in Polish People's Republic till 1953
}

\begin{abstract}
In the years 1944-1948, the authorities of communist Poland, for tactical reasons abstained from direct attacks on the Catholic Church. After the establishment of the authorities' structures and once the political opposition and armed forces underground were defeated, systematic restriction on the influence of the Church begun. Back then, the Catholic Church was the only independent social institution in the country. What was attacked then was, among others, religious education in schools (religious education, crosses and catechists were removed from schools, Catholic education was limited), catholic organisations, charitable and care activities of the Church (at the beginning of 1950, the state took over "Caritas" and kindergartens, children's homes, hospitals were taken from the Church) as well as publishing activities (Catholic press releases were being restricted). The repressions were hindered by the signature of the ChurchState Agreement in April 1950. When in 1952, the activities aimed at the removal of religious education from schools were intensified, several dozens of theological seminaries were dissolved and some of the boarding-schools run by the Church were taken over, then Primate Stefan Wyszyński defined the relations between the Church and the State as a "state of emergency".
\end{abstract}

\section{Keywords}

Catholic Church, communist government, anti-Church policy, Stalinism 
During World War II, the Catholic Church in Poland fell victim to repressions, but the fact that it was also a martyr's Church that remained the depositary of patriotism in times of German and Soviet occupation resulted in the increase of its authority in the society. Change of the country's borders and of the structure of nationalities and religious beliefs of the Polish society only strengthened the standing of the Catholic Church that became the "monopolist in the field of beliefs" (in the inter-war period, the Roman Catholics amounted to $66 \%$ of society while after the war their percentage amounted to more than $90 \%) .{ }^{1}$ Yet, it had to face a new political reality, the communist authorities which believed in different values - materialistic atheism. This meant inevitable confrontation, yet the primate (since 1948) Stefan Wyszyński urged to remain calm and referred to the 2,000 years of continuous existence of the Church in different conditions that "will not be surprised even today, even if faced with communist world. It will remain the calm Farmer who sows his seeds. That is why the Polish Church with great tranquillity will face the communist reality, not fearing it has to coexist with this reality."

The new authorities were aware of their weak position, the lack of sincere support and roots in the society and of the fact that the opposition Polish People's Party and the political and armed forces underground were a real threat. Due to tactical issues, at the beginning there were no open activities against the Church. The authorities even officially declared freedom of conscience, as well as equality of all citizens no matter their religious beliefs (such a declaration was made in the policy paper of the usurper "government": The Manifesto of the Polish Committee of National Liberation of July 1944). Even

1 There are many papers on the functioning of the Catholic Church in the communist Poland. The most important comprise syntheses concerning the whole country: J. Żaryn, Dzieje Kościoła katolickiego w Polsce (1944-1989), Warszawa 2003; J. Żaryn, Kościół a władza w Polsce (1945-1950), Warszawa 1997; Z. Zieliński, Kościół w Polsce 1944-2002, Radom 2003; A. Dudek, R. Gryz, Komuniści i Kościół w Polsce (1945-1989), Kraków 2003; A. Dudek, Państwo i Kościół w Polsce 1945-1970, Kraków 1995; B. Noszczak, Polityka państwa wobec Kościoła rzymskokatolickiego $w$ Polsce $w$ okresie internowania prymasa Stefana Wyszyńskiego 1953-1956, Warszawa 2008. Papers discussing this problem in regional context include, among others: R. Gryz, Państwo a Kościół w Polsce 1945-1956 na przykładzie województwa kieleckiego, Kraków 1999; B. Stanaszek, Diecezja sandomierska w powojennej rzeczywistości politycznej w latach 1945-1967, vol. 1, Problematyka personalno-organizacyjna, vol. 2, Duszpasterstwo i laicyzacja życia społecznego, Sandomierz 2006; A. Dziurok, Kruchtoizacja. Polityka władz partyjno-państwowych wobec Kościoła katolickiego w latach 1945-1956 w województwie śląskim/ katowickim, Katowice 2012.

2 S. Wyszyński, Pro memoria, vol. I: 1948-1952, Warszawa 2017, p. 372. 
Ivan Serov, NKVD general responsible for repressions against the Church, advised caution in anti-Church activities as he noticed that for the first time the Soviets are in a country that is mostly Catholic and thus the methods used should be "slower and more delicate"3 (thus Primate Wyszyński was right when, years later, he wrote that Moscow is responsible for the fight against the Church in Poland, while the Polish United Workers' Party only carries it out ${ }^{4}$ ). When communist authorities were installing themselves in Poland they avoided more serious disagreements with the Church, although conflicts did happen if only when the Concordat with Holy See was ended (12 September 1945) or when a decree was passed on Civil Registry Records that facilitated divorces and introduced mandatory civil marriages (25 September 1945). In general, till 1948 we can observe a period of mutual "passing by" between the State and the Church, between the "matter and the spirit." The Church was free to reconstruct its structures and institutions, carry out religious education in schools and even receive help from the state in terms of rebuilding destroyed churches. As noticed by the editor of "Trybuna Robotnicza" (organ of the communist party) published in Katowice, in terms of religious policies, the authorities followed the steps of "Machiavelli rather than Marx" - "the end justifies the means" rule. This policy was abandoned after the electoral fraud of the Polish election of January 1947 and once the opposition of the political and armed forces underground was defeated. The year 1948 marked the beginning of the ideological offensive that defined the Church, then the only independent social structure, as an obstacle in establishing anew social and political order. ${ }^{7}$ Such an approach was proclaimed in December 1948 during theunification congress of worker's parties, stating that the party will fight "all clerical aspirations" that aim to subject the political and social order to clergy's influence. The basis of Church-State relations was to be the separation of Church and State, as well

3 Z. Błażyński, Mówi Józef Światło. Za kulisami bezpieki i partii 1940-1955, Londyn 1985,p. 174.

${ }^{4}$ Primate stated that if not for the pressure from Moscow, this fight would be different, S. Wyszyński, Pro memoria, vol. I, p. 137.

${ }^{5}$ J. Żaryn, Dzieje Kościoła katolickiego w Polsce (1944-1989)..., p. 75-87.

${ }^{6}$ A. Dziurok, Kruchtoizacja..., p. 46.

${ }^{7}$ More on this, among others, in.: T. Krawczak, Kościół w Polsce w 1948 r., in: Zwrot polityczny '48. Między polska droga a projektem uniwersalnym, ed. M. Jabłonowski, W. Jakubowski, T. Krawczak, Warszawa 2013, p. 389-410. 
as secularism of the education and of all public authorities. ${ }^{8}$ Also the Security Services increased their operational activities against the Church environment. As early as October 1947, the Minister of Public Security declared that "the most organized reactionary authority characterized by the highest level of unification and almost untouched by us is definitely the clergy." of structures and people of the Church started to have first noticeable effects only in mid-1949. ${ }^{10}$ It was also then that a breakthrough in the agents' recruitment in Church structures was made. During Stalinism, the Office of Public Security used several hundred of agents and informers, both among clergy and laity, for its operations. ${ }^{11}$

At the end of 1948 the Primate Cardinal August Hlond died, and a new Primate of Poland was appointed, Bishop Stefan Wyszyński, coinciding with the anti-Church offensive (this is also the beginning of the Stalinist regime in Poland). One of the first major "blows" during this war was the declaration of the Minister of Public Administration, Władysław Wolski, of March 1949 on anti-State attitude of Church hierarchy. He directed his accusations towards two bishops in particular (the Bishop of Kielce, Czesław Kaczmarek and Bishop of Katowice Stanisław Adamski) who allegedly were leading the "anti-people's republic activities", accusing them of a servile attitude towards the German invader. ${ }^{12}$ As a result of this declaration, a mass propaganda campaign started the aim of which was, among others, to introduce division among clergy. The Security Services carried out these disintegration goals by "isolating [...] reactionary, fighting element from the masses and from the clergy that avoids

${ }^{8}$ Deklaracja ideowa Polskiej Zjednoczonej Partii Robotniczej, grudzień 1948 r., in: Historia polityczna „ludowej” Polski 1944-1989. Wybór źródeł dla studentów politologii, selection and preparation: F. Musiał, R. Terlecki, M. Wenklar, Kraków 2013, p. 60.

9 Aparat bezpieczeństwa w latach 1944-1956. Taktyka, strategia, metody, cz. 1: Lata 19451947, preparation A. Paczkowski, Warszawa 1994, p. 200-201.

${ }^{10}$ Cf. Instrukcje, wytyczne, okólniki dyrektor Departamentu V MBP dotyczące działań przeciwko Kościołowi katolickiemu w latach 1945-1953, selection and preparation: A. Dziurok, J. Marecki, F. Musiał, introduction A. Dziurok, F. Musiał, Kraków-Katowice 2012.

${ }^{11}$ Cf. A. Dziurok, Wstęp, in: Metody pracy operacyjnej aparatu bezpieczeństwa wobec Kościołów i związków wyznaniowych 1945-1989, ed. A. Dziurok, Warszawa 2004, p. 61-62.

12 Declaration of the Minister of Public Administration, Władysław Wolski, on antiState approach of Church hierarchy and regulation of the relationship between the State and the Church, 14 March 1949, in: P. Raina, Kościót katolicki a państwo w świetle dokumentów 1945-1989, t. 1: lata 1945-59, Poznań 1994, p. 142-143. 
political conflict with the Government."13 The program of internal Church disintegration was completed by the establishment of the "Patriot priests" movement based on the Soviet example implemented in the Eastern Bloc countries (the Primate called them "politician priests" ${ }^{14}$ ). It took on the shape of an isolated body (Priests Committee) attached to Society of Fighters for Freedom and Democracy, a veterans' association. Due to the efforts of Minister of Public Security in 1949 the structures of this organisation were established, and several hundred members were recruited - they were clergymen who declared loyalty towards the government. These priests were used, among others, to attack the Church hierarchy and the Holy See. ${ }^{15}$ As soon asat the end of 1950, the "patriotic" division of the Church was joined by a group referred to as "priests intellectuals" acting on behalf of Committee of Catholic Intellectuals and Activists at the Polish Peace Committee. It was affiliated with PAX Association, a group established by Bolesław Piasecki, centred around "Dziś i Jutro", a weekly newspaper, disseminating the utopian ideas of Christianization of socialism. ${ }^{16}$ These circles could count on the support of the government that systematically eliminated hostile groups in the Church. The "Tygodnik Warszawski" newspaper has already been closed as early as in 1948. It was the last platform of the Church that questioned the Marxist rules (the editor-in-chief, Fr Zygmunt Kaczyński was sentenced to many years in prison where he died). Limiting the market of Catholic press resulted in the fact that the Church and monastic printing houses were taken over by the state (in spring 1949), the allotment of paper was reduced and multiple obstacles in distribution were introduced. Catholic

13 Minister of Public Security, StanisławRadkiewicz, report opening the meeting of Ministry of Public Security (excerpt), 23 March 1949, in: Instrukcje, wytyczne, okólniki dyrektor Departamentu V MBP, p. 325.

${ }^{14}$ S. Wyszyński, Pro memoria, vol. I, p. 406.

15 The "Patriot priests" movement was an implementation of Joseph Stalin's recommendation who, in a conversation with Bolesław Bierut, lectured him: "With the clergy you can do nothing unless you divide it into two separate and opposing groups" cf.: J. Żurek, Ruch „księży patriotów" w województwie katowickim 1945-1956, Warszawa-Katowice 2009; B. Bankowicz, Ruch księży patriotów 1949-1955, czyli „koń trojański” wpolskim Kościele katolickim, in: B. Bankowicz, A. Dudek, Ze studiów nad dziejami Kościoła i katolicyzmu w PRL, Kraków 1996, p. 5-24; A. Dudek, Sutanny w stużbie Peerelu, „Karta” 1998, no. 25, p. 110-128; J. Żaryn, „Księża patrioci” - geneza powstawania formacji duchownych katolickich, in: Polska 1944/45-1989. Studia i materiały, vol. 1, Warszawa 1995, p. 123-150.

16 A. Dudek, R. Gryz, Komuniści i Kościót w Polsce (1945-1989)..., p. 72. 
publishing houses had to face censorship, which began to interfere even with religious texts. ${ }^{17}$

The religious policies of the government in the year 1949 left the Church no doubts in terms of "passing by" the state. This was confirmed by propaganda activities (among others after the issue of the Holy Office Decree of 1 July 1949 that threatened to excommunicate those Catholics who were members of the communist party or supported it ${ }^{18}$ ), as well as by restrictive legislative. In August 1949, a decree on the freedom of conscience and faith was issued providing for imprisonment for the "misuse" of freedom of conscience "for purposes that are a threat to the order". At the same time, the Episcopate decided to disband a majority of catholic associations (among others the Sodality of Our Lady), informing the faithful that this is due to a governmental decree. That is because the government provided for the need to submit members' lists of associations to administration bodies, which was correctly understood as a tool to victimize lay Catholics. ${ }^{19}$

The anti-Church policy was carried out under the slogan to fight the use of religion for political purposes. The government tried to avoid the accusation of fighting religion per se, being aware that "the fight with a cult at this stage would be an act of adventurism". The strictly religious activities of the Church were also being restricted: the organisation of public processions (especially Corpus Christi processions), pilgrimages, retreats and parish missions were hindered. ${ }^{20}$

What became the priority of the religious policies of communist government was taking over the influence over the education of the young generation. The fight for the souls of the youth took place in schools, from which the influence of the Church was being eradicated. The secularisation of education that begun in 1948 that was carried out methodically and systematically was about eliminating religion, priests and catechists from schools, limiting the development and elimination of church education (according to the Primate, it was a "vulgar

17 Cf. J. Stefaniak, Polityka władz państwowych PRL wobec prasy katolickiej w latach 19451953, Lublin 1998.

18 Episcopal Letter to the Government on Holy Office Decree, 1 August 1949 r., in: P. Raina, Kościót w PRL..., vol. 1, p. 163-164.

19 Komunikat Episkopatu Polski o rozwiązaniu zrzeszeń religijnych w Polsce, Jasna Góra 20-21 IX 1949 r., in: Komunikaty Konferencji Episkopatu Polski 1945-2000, introduction and preparation: J. Żaryn, Poznań 2006, p. 54.

20 A. Dziurok, Priorytety polityki wyznaniowej władz Polski ,ludowej” w okresie stalinowskim, „Glaukopis” (2016), no. 33, p. 227-253. 
theft" ${ }^{21}$ ), removing religious symbols from schools and making it difficult for school children to perform religious duties. Every effort was made to open new, competing lay educational institutions that did not teach religion (attached to the Children's Friends Association). ${ }^{22}$ But the secularisation activities were carried out also outside of schools, for example during summer camps (participation in Sunday mass was hindered and praying was forbidden). ${ }^{23}$

By implementing the programme of eliminating the influence of the Church the Community government also deprived the Churchof "Caritas", anorganisation that was "the last bastion of Church presence in social life." ${ }^{24}$ Its influence can be confirmed by the fact that in 1947, Caritas run 972 kindergartens and more than 1,800 care facilities throughout the country, providing food, financial and moral aid. In January 1950, a winding-up procedure was carried out on the grounds of alleged abuse and mismanagement. The Church-owned "Caritas" was replaced by a government-supervised Catholics Association "Caritas", which took over the kindergartens, children's homes and orphanages. ${ }^{25}$ Two months later, an act on land accumulating in mortmain deprived the Church of more than $95 \%$ of land significantly weakening its material standing and possibilities in terms of reaction. Additionally, the profit from the appropriated church properties was allocated to a special Church Fund which was then allocated to anti-church activities including for the purpose of the development of "patriot priests" movement. ${ }^{26}$ Earlier, as in the years $1948-1949$, the process of taking

${ }^{21}$ S. Wyszyński, Pro memoria, vol. I, p. 122.

${ }^{22}$ Cf. H. Konopka, Religia w szkołach Polski Ludowej. Sprawa nauczania religii w polityce państwa (1944-1961), Białystok 1997.

${ }^{23}$ M. Brodala, A. Lisiecka, T. Ruzikowski, Przebudować człowieka. Komunistyczne wysiłki zmiany mentalności, Warszawa 2001, p. 43; K. Kosiński, O nowa mentalność. Życie codzienne w szkołach 1945-1956, Warszawa 2000, p. 93.

${ }^{24}$ Z. Zieliński, Kościół w Polsce..., p. 63.

${ }^{25}$ Once the Church-owned "Caritas" was eliminated, only 16 institutions were left in the hands of the Church, managed by orders having the status of private nursing homes, cf D. Zamiatała, „Caritas”. Działalność i likwidacja organizacji 1945-1950, Lublin 2000; E. Kaczmarek, Dlaczego przeszkadzały? Polityka władz partyjnych i rzadowych wobec żeńskich zgromadzeń zakonnych $w$ Polsce $w$ latach 1945-1956, Warszawa 2007, p. 190-191, 194; J. Żaryn, Kościół a władza w Polsce..., p. 276-278; A. Szymański, Proces likwidacji działalności charytatywnej Kościoła katolickiego w sferze publicznoprawnej w latach 1944-1965. Studium historyczno-prawne, Opole 2010,p. 152.

${ }^{26}$ J. Marecki, Stosunki państwo-Kościół w okresie stalinowskich represji, in: Stosunki PaństwoKościół w Polsce 1944-2010. Studia i materiały, ed. R. Łatka, Kraków 2013, p. 31; A. Mirek, 
over church hospitals had begun. The declericalization of health institutions meant the removal of nuns employed as nurses. ${ }^{27}$

Weakening the level of Church social influence (taking over of "Caritas") and a blow to its material support induced the Church hierarchy to negotiate with the government. Primate Wyszyński, who from the very beginning wanted to enter into a guarantee arrangement with the authorities, led to the signature of a Church-State Agreement (14 April 1950). In a situation when the Concordat was no longer binding, the Agreement gave the Church a legal protection of free functioning. The price were minor concessions to the benefit of the people's republic authorities, including lack of objection to the collectivization of the cultural sector and condemnation of "murderous activities of the underground gangs" and of all anti-state acts. When the communist government tightened the anti-church policies, the Episcopate consequently invoked the Agreement provisions. It was a buffer that probably postponed by several years. the most severe repressions directed towards the Church. This is also how Primate Wyszyński interpreted that situation, being aware of the unavoidable conflict between Christianity and godlessness. He claimed that one had to "win some time to strengthen oneself to protect the God's positions." ${ }^{28}$

Soon after the Agreement was signed, the Office for Religious Affairs was established. It had to deal with religious policies of the state, obut in fact became an administrative tool for anti-Church repressions. The communist government wanted to gain maximum control over the Church and the means to do that was to take control over its personnel policy. The first attempt at "Czechization" of the Polish Church (meaning establishing pro-communist vicars capitular to administer the dioceses, as it was done in Czechoslovakia) took place on the so-called Recovered Territories where there was no fixed church structure. In January 1951, five Holy See administrators were removed from these areas and the chapters appointed the candidates indicated by the authorities to the position of vicars capitular. At the same time, the Bishop of Kielce, Czesław Kaczmarek, was arrested. According to Primate Wyszyński, the case of Kielce Curia was to be a training ground - "a testing ground for the fight with Church

Ustawa o przejęciu dóbr „martwej ręki” - zamach na życie zakonne w Polsce, „Śląskie Studia Historyczno-Teologiczne" 2003, vol. 36, issue 1, p. 170.

27 Till 1954, almost all hospitals and rehabilitation centres managed by orders were taken over by the state, A. Szymański, Proces likwidacji działalności charytatywnej..., p. 106, 130-131.

28 S. Wyszyński, Zapiski więzienne, Paryż 1982, p. 21. 
hierarchy." ${ }^{29}$ In November 1952, three bishops of Katowice were removed from the diocese for petitioning to keep religion in schools. As a result of pressures and blackmail from the communist government, the diocese was taken over by one of the "patriot priests." ${ }^{30}$ At the same time, the repressions moved to the neighbouring archdiocese of Kraków, where the arrests were made in the curia. Even one of the archbishops went to prison, Eugeniusz Baziak, as well as his suffragan bishop, who were accused of tolerating espionage and foreign exchange dealings in the curia. ${ }^{31}$ In the Stalinist period, as many as 10 dioceses and apostolic administrations (out of 25) were deprived of rightful administrators. ${ }^{32}$ The extent of interference into the internal personnel policy of the Church can be confirmed by the fact that by the end of 1952 more than 400 priests were moved to other posts at the request of state authorities. Additionally, the action of removing religion from schools gained momentum, and 46 lower theological seminaries were dissolved (by July 1952).

The progressing marginalization of the Church can be confirmed by the fact that the so-called Catholic constitutional demands submitted by the Episcopate during the (alleged nationwide) discussion on the new constitution were completely ignored. The basic law passed in July 1952 confirmed that the Church was limited in its actions in the public sphere. Thus, the rule, then introduced, stating that "the Church is separate of the State" was a model of the so-called hostile separation, as a part of which the Church was moved to the margins of social life. The government strived to root "all the healthy and lively elements" out of the Church and leave only the clergy margin (defined as "sacristy begging and church ignorance"). Within this idea, the Church was to be excluded from the possibility to influence the social life and was forced to limit its activity to the church walls, therefore, we can talk about the process of the so-called "sacristisation" or the model of the so-called sacristy pastoral work. ${ }^{33}$

29 S. Wyszyński, Pro memoria, vol. I: 1948-1952, Warszawa 2017, p. 108.

${ }^{30}$ Cf. A. Grajewski, Wygnanie. Diecezja katowicka w czasach stalinowskich, Katowice 2002.

31 Well-known "Stalinist show trial of the Kraków Curia" was one of the numerous show trials that aimed to undermine the authority of the clergy among the faithful, F. Musiał, M. Lasota, Kościót zraniony. Sprawa ks. Lelity i proces Kurii krakowskiej, Kraków 2003.

32 J. Żaryn, Dzieje Kościoła katolickiego w Polsce..., p. 147.

33 A. Dziurok, Kruchtoizacja..., p. 54; P. Mardyła, Duszpasterstwo w czasach stalinowskich. Władze komunistyczne wobec działalności duszpasterskiej Kościoła rzymskokatolickiego w archidiecezji krakowskiej w latach 1945-1956, Kraków 2009, p. 11. 
The last attempt to resolve the conflict between the Church and State amicably can be the declaration of the Episcopate of December 1952. By referring to the events that took place in the Kraków Curia the bishops condemned the participation of the clergy in "underground activities and economic diversion", which could be understood as a compromise and indirect declaration of loyalty. ${ }^{34}$ The communist government still sought further confrontations, paying no heed to the words of the Office for Religious Beliefs director, Antoni Bida, who warned that "a course directed to the elimination of the Church, war with the religion, fighting faith" would suit the church hierarchy as then it could pose itself as a persecuted institution, "wear the martyr's crown, sail under the colours of defenders of faith."35

\section{Bibliography}

Aparat bezpieczeństwa w latach 1944-1956. Taktyka, strategia, metody, cz. 1: Lata 1945-1947, preparation A. Paczkowski, Warszawa 1994.

Bankowicz B., Ruch księży patriotów 1949-1955, czyli „koń trojański” w polskim Kościele katolickim, 4 in: B. Bankowicz, A. Dudek, Ze studiów nad dziejami Kościoła i katolicyzmu w PRL, Kraków 1996.

Błażyński Z., Mówi Józef Światło. Za kulisami bezpieki i partii 1940-1955, Londyn 1985.

Brodala M., Lisiecka A., Ruzikowski T., Przebudować człowieka. Komunistyczne wysiłki zmiany mentalności, Warszawa 2001.

Dudek A., Gryz A., Komuniści i Kościół w Polsce (1945-1989), Kraków 2003.

Dudek A., Państwo i Kościół w Polsce 1945-1970, Kraków 1995.

Dudek A., Sutanny w stużbie Peerelu, „Karta” (1998), no. 25.

Dziurok A., Kruchtoizacja. Polityka władz partyjno-państwowych wobec Kościoła katolickiego w latach 1945-1956 w województwie śląskim/katowickim, Katowice 2012.

Dziurok A., Priorytety polityki wyznaniowej władz Polski „ludowej" w okresie stalinowskim, „Glaukopis” (2016), no. 33.

Grajewski A., Wygnanie. Diecezja katowicka w czasach stalinowskich, Katowice 2002.

Gryz R., Państwo a Kościót w Polsce 1945-1956 na przykładzie województwa kieleckiego, Kraków 1999.

Historia polityczna ,ludowej” Polski 1944-1989. Wybór źródeł dla studentów politologii, selection and preparation: F. Musiał, R. Terlecki, M. Wenklar, Kraków 2013.

34 A. Dudek, R. Gryz, Komuniści i Kościół w Polsce (1945-1989) ..., p. 80.

${ }^{35}$ Central Archives of Modern Records, Office of Religious Affairs, file no. 127/12, Protocol of voivodeship managers meeting of the Department for Religious Affairs 25 IV 1951, p. 251. 
Instrukcje, wytyczne, okólniki dyrektor Departamentu V MBP dotyczace działań przeciwko Kościołowi katolickiemu w latach 1945-1953, selection and preparation: A. Dziurok, J. Marecki, F. Musiał, introduction A. Dziurok, F. Musiał, Kraków-Katowice 2012.

Kaczmarek E., Dlaczego przeszkadzały? Polityka władz partyjnych i rzadowych wobec żeńskich zgromadzeń zakonnych w Polsce w latach 1945-1956, Warszawa 2007.

Komunikaty Konferencji Episkopatu Polski 1945-2000, introduction and preparation: J. Żaryn, Poznań 2006.

Konopka H., Religia w szkołach Polski Ludowej. Sprawa nauczania religii w polityce państwa (1944-1961), Białystok 1997.

Kosiński K., O nowa mentalność. Życie codzienne w szkołach 1945-1956, Warszawa 2000.

Krawczak T., Kościół w Polsce w 1948 r., in: Zwrot polityczny '48. Między polska droga a projektem uniwersalnym, ed. M. Jabłonowski, W. Jakubowski, T. Krawczak, Warszawa 2013.

Łatka R., Marecki J., Kościół katolicki w Polsce rządzonej przez komunistów, Warszawa 2017.

Mardyła P., Duszpasterstwo w czasach stalinowskich. Władze komunistyczne wobec działalności duszpasterskiej Kościoła rzymskokatolickiego w archidiecezji krakowskiej w latach 1945-1956, Kraków 2009.

Marecki J., Stosunki państwo-Kościół w okresie stalinowskich represji, in:Stosunki PaństwoKościót w Polsce 1944-2010. Studia i materiały, ed. R. Łatka, Kraków 2013.

Metody pracy operacyjnej aparatu bezpieczeństwa wobec Kościołów i związków wyznaniowych 1945-1989, ed. A. Dziurok, Warszawa 2004.

Mirek A., Ustawa o przejęciu dóbr „martwej ręki” - zamach na życie zakonne w Polsce, „Śląskie Studia Historyczno-Teologiczne” 2003, vol. 36, z. 1.

Musiał F., Lasota M., Kościół zraniony. Sprawa ks. Lelity i proces Kurii krakowskiej, Kraków 2003.

Noszczak B., Polityka państwa wobec Kościoła rzymskokatolickiego w Polsce w okresie internowania prymasa Stefana Wyszyńskiego 1953-1956, Warszawa 2008.

Raina P., Kościół katolicki a państwo w świetle dokumentów 1945-1989, vol. 1:lata 1945-59, Poznań 1994.

Stanaszek B., Diecezja sandomierska w powojennej rzeczywistości politycznej w latach 1945-1967, vol. 1, Problematyka personalno-organizacyjna, vol. 2, Duszpasterstwo i laicyzacja życia społecznego, Sandomierz 2006.

Stefaniak J., Polityka władz państwowych PRL wobec prasy katolickiej w latach 1945-1953, Lublin 1998.

Szymański A., Proces likwidacji działalności charytatywnej Kościoła katolickiego w sferze publicznoprawnej w latach 1944-1965. Studium historyczno-prawne, Opole 2010.

Wyszyński S., Pro memoria, vol. I: 1948-1952, Warszawa 2017.

Wyszyński S., Zapiski więzienne, Paryż 1982.

Zamiatała D., „Caritas”. Działalność i likwidacja organizacji 1945-1950, Lublin 2000.

Zieliński Z., Kościół w Polsce 1944-2002, Radom 2003. 
Żaryn J., „Księża patrioci” - geneza powstawania formacji duchownych katolickich, in: Polska 1944/45-1989. Studia i materiały, vol. 1, Warszawa 1995.

Żaryn J., Dzieje Kościoła katolickiego w Polsce (1944-1989), Warszawa 2003.

Żaryn J., Kościół a władza w Polsce (1945-1950), Warszawa 1997.

Żurek J., Ruch „księży patriotów” w województwie katowickim 1945-1956, WarszawaKatowice 2009. 